\title{
Respon Guru Tentang Pelanggaran yang dilakukan Siswa (Studi Kasus di SDN 10 Pajo)
}

\author{
Arifin'1, Sugerman' ${ }^{2}$, M. Amin ${ }^{3}$ \\ ${ }^{1}$ Dosen Program studi Pendidikan Teknologi Informasi, STKIP Yapis Dompu \\ 2,3 Dosen Program Studi Pendidikan Bahasa dan Sastra Indonesia, STKIP Yapis Dompu \\ E-mail: arifinku1212@gmail.com, sugerman.erman@gmail.com
}

Article History: Received: 2021-07-22 || Revised: 2021-07-28 || Published: 2021-08-23

Sejarah Artikel : Diterima: 2021-07-22 || Direvisi: 2021-07-28 || Dipublikasi: 2021-08-23

\begin{abstract}
This study uses a qualitative approach, with a phenomenological case study design. Analysis of the data used is phenomenological analysis. The results of the research on teacher responses at SDN 10 Pajo regarding student violations are: 1) Student violations are deviant behavior, namely by violating school rules, thus disrupting the learning atmosphere and harming other individuals; 2) The forms of student violations are categorized into 2, namely disruptive behavior and serious student violations. 3) there are 6 causes of student violations, namely: physical condition, lack of parental attention (moral education and economic support), teacher learning methods that are less varied (monotonous), language that is difficult for students to understand, negative environment, and too many subject matter; 4) How to overcome student violations, namely: providing models for students, verbal reprimands, physical sanctions, special attention, manipulating assignments, providing substitute activities, manipulating seating locations, providing special understanding, providing learning grids, communicating with parents, provide rules, provide good and bad choices, refraction, provide failure experiences, provide motivation, communicate privately with students, and return to parents.
\end{abstract}

Keywords: Perception, Teacher, Student's delinquency, Primary school.

\begin{abstract}
Abstrak
Penelitian ini menggunakan pendekatan kualitatif, dengan rancangan studi kasus fenomenologis. Analisis data yang digunakan yaitu analisis fenomenologis. Hasil penelitian terhadap respon guru SDN 10 Pajo tentang pelanggaran siswa yaitu: 1) Pelanggaran siswa adalah perilaku menyimpang yakni dengan melanggar peraturan sekolah, sehingga mengganggu suasana belajar dan merugikan individu lain; 2) Bentuk pelanggaran siswa dikategorikan menjadi 2, yaitu perilaku mengganggu dan pelanggaran serius siswa. 3) terdapat 6 penyebab pelanggaran siswa yaitu: kondisi fisik, kurangnya perhatian orang tua (pendidikan moral dan dukungan ekonomi), metode pembelajaran guru yang kurang bervariasi (monoton), bahasa yang sulit dipahami siswa, lingkungan negatif, dan materi pelajaran terlalu banyak; 4) Cara mengatasi pelanggaran siswa, yaitu: pemberian model bagi siswa, teguran verbal, sanksi fisik, perhatian khusus, memanipulasi pemberian tugas, memberikan aktivitas pengganti, memanipulasi lokasi tempat duduk, memberikan pemahaman khusus, memberikan kisi-kisi belajar, berkomunikasi dengan orang tua, memberikan peraturan, memberikan pilihan baik-buruk, pembiasan, memberikan pengalaman gagal, memberikan motivasi, berkomukasi secara pribadi dengan siswa, dan dikembalikan kepada orang tua.
\end{abstract}

Kata kunci: Respon, Guru, Pelanggaran siswa, Sekolah Dasar

\section{PENDAHULUAN}

Pada anak-anak usia sekolah dasar, umumnya berada dalam proses perkembangan yang berlangsung dengan cepat dalam aspek fisik, emosional, intelektual dan sosial. Dalam tahap perkembangan tersebut, tak jarang anak mengalami hambatan atau bahkan melakukan perilaku yang keliru yang dapat merugikan mereka, baik untuk dirinya sendiri maupun orang lain. Perilaku yang dicerminkan dapat berupa perilaku yang positif dan perilaku yang negative. Salah satunya yaitu berupa perilaku pelanggaran. Pelanggaran pada anak dimaknai sebagai suatu bentuk perilaku yang tidak sesuai dengan norma-norma yang hidup di tengah masyarakat. Perilaku yang tidak sesuai dengan norma itu dianggap sebagai anak yang cacat social dan kemudian masyarakat menilai cacat tersebut dianggap sebagai sebuah kelainan sehingga perilaku mereka pun disebut dengan pelanggaran. Pada umumnya pelanggaran atau istilah lain Deliquency merupakan produk 
konstitusi defektif dari mental dan emosi- emosi, yaitu mental dan emosi anak muda yang belum matang (labil) dan jadi rusak (defektif) sebagai akibat proses pengondisian oleh lingkungan yang buruk. Kartini Kartono, Psikologi Anak (Psikologi Perkembangan) (Bandung: CV.Mandar Maju, 2007), hal. 227.

Siswa di Sekolah Dasar (SD) akan mengalami masalah-masalah yang berkenaan dengan : Pertama, perkembangan individu. Kedua, perbedaan individu dalam hal : kecerdasan, kecakapan, hasil belajar, bakat, sikap, kebiasaan, pengetahuan, kepribadian, cita-cita, kebutuhan, minat, pola-pola, dan tempo perkembangan, ciri-ciri jasmaniah dan latar belakang lingkungan. Ketiga, kebutuhan individu dalam hal: memperoleh kasih sayang, memperoleh harga diri, memperoleh penghargaan yang sama, ingin dikenal, memperoleh prestasi dan posisi, untuk dibutuhkan orang lain, merasa bagian dari kelompok, rasa aman dan perlindungan diri, dan untuk memperoleh kemerdekaan diri. Keempat, penyesuaian diri dan kelainan tingkah laku. Kelima, masalah belajar, Perilaku yang sering terjadi pada anak adalah perilaku agresif. Perilaku agresif secara psikologi cenderung (ingin) menyerang kepada sesuatu yang dipandang sebagai hal yang mengecewakan, menghalangi atau menghambat. Perilaku ini terjadi pada masa perkembangan, karena pada masa inilah seorang anak sudah mulai merasa ingin mengetahui dan ingin melakukan sesuatu yang dia inginkan walaupun tanpa dia sadari sesuatu yang dia lakukan itu dapat berdampak negative pada dirinya sendiri ataupun pada orang lain. Elizabeth Hurlock, Perkembangan Anak (Jakarta : Erlangga), hal.13.

Perilaku agresif sesungguhnya merupakan reaksi normal pada anak-anak yang masih kecil (usia 2-3 tahun). Anak-anak secara naluriah akan memunculkan perilaku ini ketika mereka merasa tidak nyaman, ketika mereka ingin melindungi diri mereka, atau ketika mereka ingin mencapai suatu tujuan tertentu namun tidak mengetahui bagaimana cara yang lebih baik untuk meraihnya. Selain itu, perilaku agresif juga merupakan cara khas anak kecil untuk menunjukkan kepada orang lain bahwa mereka tidak suka pada apa yang dilakukan orang lain terhadap mereka. Akan tetapi, seiring dengan bertambahnya usia mereka, anak-anak seharusnya menjadi semakin mampu menggunakan cara-cara yang lebih tepat untuk meraih tujuannya, sehingga tidak perlu bertindak dengan cara yang agresif, Perilaku agresif menjadi bagian dari tahapan perkembangan mereka dan sering kali menimbulkan masalah, baik itu di rumah, sekolah ataupun dalam suatu kelembagaan yang mana disuatu tempat tersebut dia dapat berinteraksi terutama dengan orang lain. Diharapkan setelah melewati usia 7 tahun, anak sudah lebih dapat mengendalikan dirinya untuk tidak menyelesaikan masalah dengan perilaku agresif, tetapi bila keadaan ini menetap, maka ada indikasi anak mengalami gangguan psikologis sehingga dapat menghambat perkembangan psikologis anak tersebut.

Secara definisi, Willis (2005) menyatakan pelanggaran anak atau (Juvenile Delinquency) berasal dari 2 istilah yaitu Juvenile dan Delinquency. Juvenile berasal dari bahasa latin "Juvenilis", yang berarti anak-anak, anak muda, sifat khas pada periode remaja (di bawah 18 tahun), sedangkan Delinquency berasal dari bahasa latin "delinquere" yang berarti terabaikan, mengabaikan, yang kemudian diperluas artinya menjadi jahat, nakal, anti sosial, kriminal, pelanggar aturan, pembuat ribut, dan lain sebagainya, Siswa yang melanggar aturan-aturan sekolah baik yang tertulis, maupun yang tidak tertulis, dapat berpotensi menimbulkan kekacauan-kekacauan yang mengganggu. Perilaku itu dapat didefinisikan sebagai perilaku mengganggu/mengacaukan (disruptive behaviour). O'Connor, dkk. (2012) menyatakan bahwa "disruptive behaviour problems............. because of their association with later delinquency and school failure". Ini berarti bahwa perilaku disruptif merupakan masalah yang mempunyai asosiasi dengan kenalakan dan kegagalan bersekolah selanjutnya. Oleh sebab itu, antara juvenile delinquency dan disruptive behaviour memang masih memiliki kesamaan apabila dilihat dari pokok permasalahannya.

Arbuckle \& Little (2004) mendefinisikan bahwa perilaku yang dapat dikategorikan dalam perilaku mengacaukan yaitu aktivitas yang membuat menyusahkan guru, mengganggu proses belajar dan membuat guru terus-menerus mengomentari siswanya. Pengertian lain dari disruptive behaviour, yang dikutip dari sebuah jurnal yang ditulis oleh Ali \& Gracey (2013), yaitu perilaku mengganggu, ikut campur, dan menghalang- halangi fungsi operasi normal, termasuk aktivitas mengajar di kelas, hak siswa untuk merasa mempunyai kesempatan senang dalam praktek pendidikan, Seperti halnya sebuah kasus atau masalah yang terjadi di kawasan Desa Temba Lae, yang mana pada anak usia 10 tahun keatas masih belum bisa mengendalikan emosinya dan belum dapat menepatkan diri dengan 
baik di lingkungannya. Perkembangan moral pada anak mempunyai aspek kecerdasan dan aspek impulsive. Anak harus belajar apa yang benar dan apa yang salah. Pohan. Masalah Anak dan Anak Bermasalah (Jakarta : Intermedia,), hal.67 Disini anak tersebut mengalami masalah agresifitas dalam kesehariannya. Berkali-kali mendapatkan hukuman baik dari orang tua maupun dari gurunya, tetapi tetap saja tidak dapat menghentikan perilaku tersebut. Oleh karena itu, untuk lebih memahami tentang perilaku agresif anak khususnya pada anak sekolah dasar, peneliti akan melakukan penelitian terhadap salah satu anak yang bermasalah.

Senada dengan pendapat tersebut, Mabeba \& Prisloo (dalam Marais \& Meier, 2010) menyatakan bahwa perilaku disruptif merupakan perilaku yang berkenaan dengan masalah kedisiplinan di sekolah yang berakibat mengganggu hak dasar siswa lainnya untuk belajar dengan aman di kondisi lingkungan belajar yang mendukung, Selanjutnya, dikutip dari sebuah edaran yang berjudul " $A$ faculty Guide to Managing Disruptive Behaviour in Classroom" dari University Of Colorado, ditemukan makna mengenai Disruptive Behaviour yaitu segala perilaku yang mencoba mencampuri kepemimpinan guru dalam mengajar atau kemampuan yang dilakukan oleh siswa untuk mengambil-ngambil kesempatan dalam pembelajaran, Kuhlenschmidt and Layne, (dalam Ali \& Gracey, 2013) menyatakan bahwa "student misbehavior may be caused by physical problems, emotional challenges, or environmental factors". Itu berarti bahwa pelanggaran siswa dapat bisa juga disebabkan oleh masalah fisik, penolakan emosional, atau faktor lingkungan.

Penelitian ini berfokus untuk mengungkap respon guru SDN 10 Pajo tentang pelanggaran siswa. Respon tersebut meleputi trespon, pandangan, pendapat tentang pelanggaran siswa, penyebab pelanggaran siswa dan upaya atau tindakan yang dilakukan oleh guru terhadap pelanggaran tersebut.

\section{METODE PENELITIAN}

Penelitian ini menggunakan pendekatan kualitatif, dengan rancangan studi kasus fenomenologis. Data yang dikumpulkan oleh peneliti yaitu berupa data fisik, tertulis, aktivitas, dan lisan, Sumber data dalam penelitian ini yaitu semua guru di SDN 10 Pajo. Data yang dikumpulkan yaitu data fisik, lisan, aktivitas, dan tertulis. Prosedur pengumpul data yang digunakan yaitu melalui teknik observasi, wawancara mendalam, dan dokumentasi. Analisis data yang digunakan yaitu analisis data fenomenoligis. Prosedur analisis data yaitu reduksi data, penyajian data, dan penarikan kesimpulan

\section{HASIL DAN PEMBAHASAN}

\section{1) Respon Guru Tentang Pelanggaran Siswa}

Guru SDN 10 Pajo berpendapat bahwa pelanggaran siswa adalah perilaku menyimpang dan melanggar peraturan sekolah yang dilakukan oleh siswa, sehingga mengganggu suasana belajar dan merugikan individu lain. Hal itu, senada dengan pernyataan Willis (2005) yang menyatakan bahwa pelanggaran remaja adalah perbuatan para remaja (di bawah usia 18 tahun) yang bertentangan dengan hukum, agama, dan norma-norma masyarakat (kriminal, anti sosial, melanggar aturan) sehingga berakibat merugikan orang lain, ketenteraman umum dan juga merusak dirinya sendiri. Usia siswa SD memang seluruhnya kurang dari 18 tahun sehingga antara pelanggaran siswa dan remaja dapat dianggap sama saja. Perbuatan anti sosial itu tercermin dari terganggunya suasana belajar sehingga sangat merugikan individu (siswa) lainnya. Sedangkan melanggar aturan yakni melanggar apa-apa yang sudah disepakati sebagai peraturan di sekolah. Selain itu, pendapat guru SDN 10 Pajo juga sejalan dengan pendapat Herlan, dkk. (2012) yang menyatakan bahwa pelanggaran remaja adalah perilaku remaja melanggar status, membahayakan diri sendiri, menimbulkan korban materi pada orang lain, dan perilaku menimbulkan korban fisik pada orang lain. Merujuk pada pendapat tersebut, siswa yang melanggar peraturan sekolah jelas bahwa siswa

\section{2) Respon Guru Tentang Bentuk-Bentuk Pelanggaran Siswa}

Guru SDN 10 Pajo meresponkan bentuk pelanggaran siswa dengan mengkategorikannya menjadi 2, yaitu pelanggaran siswa berupa perilaku mengganggu dan pelanggaran serius siswa. Hal itu sesuai dengan pendapat O'Connor, dkk. (2012) yang menyatakan bahwa "disruptive behaviour problems ............ because of their association with later delinquency and school failure". 
Ini berarti bahwa perilaku menganggu merupakan masalah yang masih mempunyai asosiasi dengan pelanggaran siswa dan kegagalan bersekolah selanjutnya. Oleh sebab itu benar bahwa pelanggaran siswa dapat dibagi dalam kategori perilaku mengganggu yang dilakukan oleh siswa. Selanjutnya, pelanggaran siswa dipahami dari sudut pandang pelanggaran serius. Hal itu sesuai dengan pendapat Reed dkk. (2009) dan Slavin (2006) yang menyatakan bahwa perilaku pelanggaran anak yang berpotensi mengacaukan yaitu gang activities (aktivitas geng), alcohol and drug abuse tersebut melanggar statusnya sebagai siswa sehingga dampaknya tentu mengganggu proses belajar dari individu lainnya di kelas.

Selanjutnya, pernyataan guru SDN 10 Pajo juga sejalan dengan Ehiemua (2014) yang menyatakan bahwa pelanggaran remaja adalah keseluruhan situasi atau perilaku melanggar hukum yang dilakukan oleh individu di bawah 18 tahun. Merujuk pada pendapat tersebut, benar bahwa melanggar peraturan sekolah yang dilakukan oleh siswa merupakan peristiwa pelanggaran siswa karena telah melakukan tindakan melanggar aturan atau hukum yang berlaku di sekolah, Pendapat lain diungkapkan oleh Sarwono (2001) yang menterjemahkan pelanggaran (delinquency) dengan menyerap arti kata dalam bahasa Belanda yaitu baldadigheid yang berarti semua perbuatan yang berlawanan dengan ketertiban umum, ditujukan pada orang, binatang, dan barang yang dapat menimbulkan bahaya, kerugian, dan kesusahan. Merujuk pada pendapat tersebut, perbuatan berlawanan dengan ketertiban umum itu dapat dimanifestasikan dengan adanya gangguan yang dilakukan oleh siswa sehingga siswa lainnya terganggu dalam proses belajarnya. Gangguan tersebut tentunya juga menimbulkan kerugian bagi siswa siswa lainnya.

Merujuk dari pendapat-pendapat ahli tersebut, benar bahwa pelanggaran siswa merupakan perilaku menyimpang dan melanggar peraturan sekolah yang dilakukan oleh siswa, sehingga mengganggu suasana belajar dan merugikan individu lain, (penyalahgunaan narkoba), dan serious property delinquent (pelanggaran yang bersifat serius). Merujuk hal tersebut, benar pernyataan guru SDN 10 Pajo bahwa pelanggaran siswa juga dapat dikategorikan dalam pelanggaran serius, Guru SDN 10 Pajo merinci bentuk perilaku mengganggu meliputi: tidak memperhatikan kerapian, tidak memperhatikan penjelasan guru, perilaku agresif; mencontek; membuat ancaman fisik dan verbal kepada guru atau siswa; mengalihkan pembicaraan dari materi pelajaran atau diskusi; tidak patuh terhadap arahan guru; Ngeyel (tetap berbicara dan tidak mengakui kesalahan). Pelanggaran serius siswa meliputi perilaku membolos dan mencuri.

\section{3) Perilaku Mengganggu Tidak Memperhatikan Kerapian}

Perilaku ini diresponkan oleh guru SDN 10 Pajo sebagai pelanggaran karena tindakan siswa tersebut dianggap kurang respek terhadap diri sendiri dan orang lain. Orang lain yang melihatnya secara visual tidak indah. Kurang menjaga kerapian baju, kuku dan rambut adalah bentuknya. Berkaitan dengan hal tersebut, memang Felker menyatakan bahwa konsep diri sangat dipengaruhi oleh penampilan fisik. Penampilan fisik yang tidak baik, sering diidentikkan oleh orang lain sebagai seseorang yang tidak memiliki inner diri yang baik. Namun Di sisi lain, ada pendapat yang berbeda mengenai perilaku tidak memperhatikan kerapian yang dianggap sebagai pelanggaran siswa oleh guru SDN 10 Pajo. Misalnya seragam sekolah siswa yang tidak sesuai dengan kaidah-kaidah mainstream rapi, yaitu baju harus dimasukkan. Mangun menyatakan bahwa siswa yang diperlakukan secara komando seperti itu, dalam hal ini harus memasukkan baju, akan kehilangan kreatifitas, spontanitas dan keceriaan alaminya. Oleh karena itu, perilaku ini tidak adil apabila dikatakan sebagai pelanggaran siswa, sedangkan siswa yang bersangkutan tidak mengganggu orang lain. Guru haruslah melihat dari sisi positifnya, misalnya kreatifitas siswa dalam memakai seragam.

\section{4) Tidak Memperhatikan Penjelasan Guru}

Perilaku tidak memperhatikan penjelasan guru dalam pembelajaran diresponkan guru SDN 10 Pajo sebagai perilaku yang merugikan individu lain di kelas dan berdampak mengganggu secara klasikal. Kondisi tersebut sesuai dengan pendapat Slavin (2006) yang menyarakan menyelesaikan permasalahan kecil dahulu sebelum menjadi permasalahan yang besar. Oleh sebab itu benar apabila permasalahan kecil, dalam hal ini perilaku tidak memperhatikan 
penjelasan guru dalam pembelajaran, akan selalu berdampak pada terganggunya kondisi kelas secara kesuluruhan.

\section{5) Perilaku Agresif}

Perilaku agresif ini diresponkan oleh guru di SDN 10 Pajo sebagai perilaku melawan terhadap hal yang bertolak dengan keinginan sehingga siswa cepat bertindak negatif kepada siswa lainnya. Hal itu memiliki kesamaan esensi dengan pendapat Hanurawan (2011) yang menyatakan bahwa perilaku agresif adalah segenap perilaku, melibatkan fisik, verbal, maupun psikologis interpersonal, yang dapat menganggu hak-hak semua siswa untuk belajar di lingkungan sekolah secara aman. Mengganggu hak-hak semua siswa ini terwujud dengan tindakan memaksakan keinginan individu kepada siswa lain, dengan konsekuensi adanya tindakan negatif apabila siswa yang agresif tersebut tidak terpenuhi keinginannya.

\section{6) Mencontek}

Guru di SDN 10 Pajo berpendapat bahwa kebiasaan mencontek merupakan perilaku negatif. Misalnya saja yang paling sederhana yaitu mengkopi atau menyalin jawaban dari teman lainnya. Representasi dari hasil tes akan sangat mengaburkan. Selain itu, perilaku ini akan menimbulkan ketergantungan pada individu lain sehingga siswa lebih cenderung untuk tidak ingin untuk belajar dengan mandiri. Hal itu sesuai dengan pernyataan Danielsen, dkk. (2006) yang menyatakan bahwa perilaku mencontek merupakan tindakan yang tidak pantas (misconduct) dilakukan di dalam lingkungan akademis. Artinya bahwa ketidakpantasan itu dikarenakan perilaku mencontek mengidentikan siswa sebagai individu yang malas untuk belajar dengan mandiri. Dampak kemalasan pada invidu serta hasil tes yang mengaburkan bagi guru tentu benar bahwa perilaku mencontek merupakan perilaku negatif yang tidak pantas seharusnya dilakukan oleh seorang siswa.

\section{7) Membuat Ancaman Fisik dan Verbal Kepada Guru Atau Siswa}

Menurut guru di SDN 10 Pajo perilaku ini dilakukan oleh siswa yang memiliki dominasi tinggi di dalam pergaulannya. Siswa melakukan hal tersebut untuk memperoleh predikat berkuasa diantara teman-temannya. Hal itu sesuai dengan pendapat Crowder, dkk. (1998) yang menyatakan bahwa perilaku kasar (mengancam, mengintimidasi) dari seorang anak dapat muncul karena anak mencoba untuk mendapatkan posisi di rumah dan di sekolah. Oleh karena itu benar bahwa perilaku ini berpeluang lebih besar terjadi apabila siswa memiliki dominasi dan kedudukan yang lebih tinggi dalam pergaulan dengan siswa lainnya.

\section{8) Mengalihkan Pembicaraan dari Materi Pelajaran atau Diskusi}

Guru di SDN 10 Pajo berpendapat bahwa perilaku mengalihkan pembicaraan dari materi pelajaran/diskusi sangat mengganggu rencana pembelajaran yang telah dibuat oleh guru. Gangguan itu juga berpotensi membuat semua siswa juga teralihkan perhatiannya. Berkaitan dengan itu, Bentham (2004) menyatakan bahwa apapun itu sejauh perilaku perilaku tersebut mengganggu, akan sangat sulit bagi guru untuk mengajar dan sangat tidak mungkin juga bagi semua siswa untuk belajar.

\section{9) Tidak Patuh terhadap Arahan Guru}

Guru di SDN 10 Pajo berpendapat bahwa perilaku tidak patuh terhadap arahan guru sering dijumpai pada siswa yang memiliki keinginan atau kehendak yang kuat, Kehendak yang kuat tersebut merupakan cara siswa untuk menunjukkan eksistensi dirinya di dalam kelas. Hal itu sesuai dengan pendapat Crowder, dkk. (2006) dan Morash \& Trojanowicz yang menyatakan bahwa memang perilaku untuk menunjukkan eksistensi diri mulai muncul di usia-usia sekolah dasar. Proses menunjukkan bahwa dirinya berarti terkadang tidak sesuai dengan nilai-nilai yang dianjurkan oleh orang yang lebih dewasa sehingga muncul sikap menolak, dan membangkang dari aturan. Merujuk pada pendapat tersebut, benar bahwa sikap tidak patuh terhadap arahan guru sering muncul pada siswa yang memiliki kehendak yang kuat untuk menunjukkan eksistensi dirinya di kelas. 


\section{0) Ngeyel (tetap berbicara dan tidak mengakui kesalahan)}

Guru SDN 10 Pajo berpendapat bahwa perilaku ini disebabkan oleh lingkungan yang abai dan permisif ketika siswa melakukan kesalahan, sehingga siswa cenderung untuk membenarkan apa yang dilakukannya, padahal perbuatannya itu adalah kesalahan. Hal itu sesuai dengan penjelasan Pressley, dkk. (2007) menyatakan bahwa ada beberapa faktor yang mempengaruhi perkembangan seorang anak, diantaranya historical era (sejarah tempat), culture (budaya), dan family life (kehidupan keluarga). Seperti yang di contohkan oleh Pressley bahwa kehidupan keluarga, dimana hampir seharian anak berinteraksi dan bersosialisasi, memiliki dampak yang sangat besar. Misalnya di dalam keluarga yang pola asuhnya otoriter, akan cenderung membentuk anak lebih berhati-hati dalam mengambil tindakan, dan begitu sebaliknya. Oleh karena itu, jika merujuk pada pendapat tersebut, perilaku Ngeyel atau tetap berbicara dan tidak mau mengakui kesalahan juga data diakibatkan oleh lingkungan siswa yang permisif terhadap segala tindakan yang salah dan tidak ada perhatian untuk membenarkan perilaku tersebut.

\section{1) Pelanggaran Serius Membolos}

Guru SDN 10 Pajo berpendapat bahwa perilaku ini memberikan kerugian bagi siswa itu sendiri dan guru sebagai pengampu di kelas tersebut. Kerugian bagi guru dan siswa yaitu guru harus mengulang kembali pembelajaran yang telah dilewatkan oleh siswa yang membolos dan siswa tentunya akan tertinggal dari siswa lainnya. Hal itu sesuai dengan pendapat Mayer, dkk. yang menyatakan bahwa salah satu masalah yang muncul dari perilaku membolos yaitu guru kehilangan waktu untuk mengajar siswa yang membolos, dan harus mengulangnya di hari yang lain. Namun Rogers berpendapat lain dengan menyatakan bahwa setiap guru harus beradaptasi dengan situasi pembelajaran, walaupun memang seorang guru harus mengikuti perencanaan pembelajaran yang sudah dibuat. Konsekuensi dari perilaku membolos sekolah memang harus ditanggung oleh guru dengan beradaptasi terhadap kondisi apapun. Siswa yang membolos memang mempunyai hak untuk dilayani sebagai individu. Oleh karena itu, kondisi ini memang merugikan bagi guru, namun konsekuensi logis yang harus dilakukan oleh guru yaitu harus tetap melayani siswa secara individu dengan mengulang kembali pembelajaran yang telah dilewatkan dari perilaku membolos yaitu guru kehilangan waktu untuk mengajar siswa yang membolos, dan harus mengulangnya di hari yang lain. Namun Rogers berpendapat lain dengan menyatakan bahwa setiap guru harus beradaptasi dengan situasi pembelajaran, walaupun memang seorang guru harus mengikuti perencanaan pembelajaran yang sudah dibuat. Konsekuensi dari perilaku membolos sekolah memang harus ditanggung oleh guru dengan beradaptasi terhadap kondisi apapun. Siswa yang membolos memang mempunyai hak untuk dilayani sebagai individu. Oleh karena itu, kondisi ini memang merugikan bagi guru, namun konsekuensi logis yang harus dilakukan oleh guru yaitu harus tetap melayani siswa secara individu dengan mengulang kembali pembelajaran yang telah dilewatkan.

\section{2) Respon Guru tentang Penyebab Pelanggaran Siswa}

Beragam respon guru menyebutkan bahwa ada 6 penyebab pelanggaran siswa yaitu: kondisi fisik, kurangnya perhatian orang tua (pendidikan moral dan dukungan ekonomi), metode pembelajaran guru yang kurang bervariasi (monoton), bahasa yang digunakan guru sulit untuk dipahami siswa, faktor lingkungan yang negatif, dan materi pelajaran terlalu banyak, Kuhlenschmidt and Layne, (dalam Ali dkk, 2013) menyatakan bahwa "student misbehavior may be caused by physical problems, emotional challenges, or environmental factors". Itu berarti bahwa pelanggaran siswa dapat bisa juga disebabkan oleh masalah fisik, penolakan emosional, atau faktor lingkungan.

Lingkungan keluarga yang menyebabkan pelanggaran siswa yaitu faktor sosial-ekonomi keluarga dan situasi keluarga tidak bahagia (broken home). Kondisi sosial-ekonomi dari keluarga yang rendah akan cenderung membuat anak berpotensi melakukan perbuatan apa saja untuk memenuhi kebutuhan sehari-harinya, yang kurang dipenuhi oleh orang tuanya. Ketidakmampuan orang tua dalam menyediakan kebutuhan materi, membuat siswa berusaha memenuhi kebutuhannya dengan apa yang pada saat itu di lihatnya (mencuri), sehingga solusinya orang tua harus dan wajib memenuhi kebutuhan siswanya. Sedangkan situasi keluarga yang tidak bahagia, biasanya akan membentuk siswa cenderung membuat kelompok dengan 
siswa yang memiliki nasib yang sama, yang kemudian akan berpotensi untuk mengganggu atau melakukan perbuatan tidak menyenangkan terhadap orang lain yang tidak senasib dengannya (Morash \& Trojanowicz,; Berger \& Gregory,; Spergel,).

Faktor metode pembelajaran guru yang monoton menjadi penyebab dari perilaku mengganggu karena siswa menjadi kurang selera terhadap materi pembelajaran yang sedang dibahas atau disajikan. Siswa mencoba untuk keluar dari apa yang menurutnya kurang menarik dengan membahas atau mengalihkan pembicaraan kelas dengan hal yang menurutnya lebih menarik. Hal itu sesuai dengan pendapat Dweretzky, (2006) dan Felker yang menyatakan bahwa memang tidak dapat dipungkiri bahwa salah satu ciri dari anak-anak dan remaja yaitu emosinya yang moody (berubah-ubah). Emosi yang kurang stabil itu juga kadang juga mempengaruhi selera siswa, termasuk selera dalam hal pembelajaran. Merujuk pada pendapat tersebut, benar bahwa berkaitan dengan selera siswa terhadap materi pembelajaran bisa menjadi penyebab siswa berperilaku mengalihkan pembicaraan dalam diskusi kelas.

Penggunaan bahasa guru yang terlalu sulit dimengerti, terlebih untuk kelas rendah, mengakibatkan proses transfer ilmu menjadi kurang berhasil pada siswa. Berkaitan dengan kedua penyebab tersebut, Kuhlenschmidt and Layne, (dalam Ali \& Gracey, 2013) menyatakan bahwa faktor lingkungan dapat menyebabkan timbulnya perilaku mengganggu. Artinya bahwa lingkungan yang tidak mendukung siswa, akan menimbulkan munculnya perilaku-perilaku menyimpang. Penyebab pertama dan kedua tersebut merupakan kegagalan guru dalam menyediakan lingkungan belajar. Lingkungan belajar tidak dikondisikan dengan baik melalui metodis dan teknis dari guru yang bersangkutan.

Kurangnya persiapan dari siswa terhadap materi yang terlalu banyak untuk dikuasai mengakibatkan perilaku mencontek ini memunculkan low self-confident (kepercayaan diri rendah). Hal itu sesuai dengan pendapat Danielsen, dkk. (2006) menyatakan bahwa memang permasalahan heavy course load (materi pelajaran yang berat dan banyak) sering menjadi penyebab umum dari perilaku mencontek. Konsekuensinya yaitu siswa memang menjadi malas dan kurang persiapan menghadapi tes yang kemudian timbul kurangnya kepercayaan diri pada siswa dalam menjawab soal-soal tesnya. Oleh karena itu, benar bahwa materi yang terlalu banyak akan mengakibatkan kurangnya persiapan dari siswa, yang otomatis akan membunuh kepercayaan diri siswa dalam menjawab soal-soal tes.

\section{3) Respon Guru dalam Mengatasi Tiap-Tiap Bentuk Pelanggaran Siswa}

Beragam respon guru mengenai cara dalam mengatasi pelanggaran siswa, yaitu: pemberian model bagi siswa, teguran verbal, sanksi fisik, perhatian khusus, memanipulasi pemberian tugas, memberikan aktivitas pengganti, memanipulasi lokasi tempat duduk, memberikan pemahaman khusus, memberikan kisi-kisi belajar, berkomunikasi dengan orang tua, memberikan peraturan, memberikan pilihan baik-buruk, pembiasan, memberikan pengalaman gagal, memberikan motivasi, berkomukasi secara pribadi dengan siswa, dan dikembalikan kepada orang tua.

\section{4) Pemberian Model bagi Siswa}

Guru di SDN 10 Pajo menggunakan teknik ini untuk mengatasi perilaku kurang memperhatikan kerapian, tidak patuh terhadap arahan guru dan agresif. Guru SDN 10 Pajo memberikan contoh kerapian kepada siswa-siswanya dan juga memberikan contoh siswa yang patuh serta tidak agresif kepada siswa yang bersangkutan. Hal tersebut sesuai dengan pandangan Bentham (2004), Dweretzky dan Felkeryang menyatakan bahwa setiap anak belajar dengan meniru. Peniruan tersebut bergantung dari model dilihat oleh siswa. Oleh karena itu, tindakan pemodelan yang dilakukan oleh guru menjadi sangat efektif apabila melihat keadaan psikologis siswa yang belajar dengan meniru seseorang di sekitarnya.

\section{5) Teguran Verbal}

Guru di SDN 10 Pajo menggunakan teguran verbal untuk mengatasi perilaku kurang memperhatikan kerapian; tidak memperhatikan penjelasan guru dalam pembelajaran; agresif; mencontek; membuat ancaman fisik dan verbal kepada guru dan siswa; serta tidak patuh terhadap arahan guru. Hal itu sesuai dengan pendapat 
Morash \& Trojanowicz (1983) mendefinisikan cara-cara pencegahan pelanggaran siswa dengan teknik Punitive Prevention atau mengambil tindakan pencegahan dengan hukuman untuk mengeliminasi potensi pelanggaran sebelum dan sesudah terjadi kasus. Teguran secara verbal langsung, merupakan pencegahan perilaku negatif dengan cara punitive prevention karena mencegah perilaku negatif terjadi lagi setelah siswa yang berperilaku negatif diberikan teguran verbal.

\section{6) Perhatian Khusus (Private Attention)}

Guru di SDN 10 Pajo menggunakan perhatian khusus (Private Attention) untuk mengatasi perilaku tidak memperhatikan penjelasan guru serta membuat ancaman fisik dan verbal. Perhatian khusus tersebut dilakukan guru dengan mengajak siswa untuk berinteraksi lebih intens dalam pembelajaran agar tercipta suasana yang akrab antara guru dan siswa. Hal tersebut sesuai dengan pendapat Spergel yang menyatakan bahwa dalam penanganan perilaku mengganggu, seorang guru harus membuka hubungan baik dengan siswa. Oleh karena itu tepat apabila guru ingin mengatasi perilaku siswa yang tidak memperhatikan penjelasan dari guru dan dalam pembelajaran dan membuat ancaman fisik dan verbal ini dengan melakukan upaya membuka hubungan baik dengan siswa melalui pemberian perhatian khusus kepada siswa yang bersangkutan.

\section{7) Memanipulasi Pemberian Tugas}

Secara khusus, guru SDN 10 Pajo menggunakan cara memanipulasi pemberian tugas untuk mengatasi perilaku tidak memperhatikan penjelasan guru dalam pembelajaran. Tugas yang diberikan lebih mudah dari biasanya. Harapan guru, siswa dapat termotivasi dengan nilai yang baik. Hal itu sesuai dengan pandangan Cullen (2011) yang menyatakan bahwa proses pengkondisian dengan memanipulasi pemberian tindakan memang terkadang perlu dilakukan untuk membantu kesuksesan seorang anak. Oleh karena itu, tepat apabila pemberian tugas yang lebih mudah dari biasanya sebagai kondisi yang dimanipulasi oleh guru, akan lebih memotivasi siswa untuk selalu memperhatikan penjelasan dari guru karena siswa yang bersangkutan akan menjadi selalu ingin mendapatkan nilai yang baik. Cara yang ditempuh, mau tidak mau, siswa harus memperhatikan penjelasan guru dalam pembelajaran.

\section{8) Memberikan Aktivitas Pengganti yang Lebih Menarik}

Guru di SDN 10 Pajo memberikan aktivitas belajar yang menarik bagi siswa untuk mengatasi perilaku mengalihkan pembicaraan dari materi pelajaran/diskusi. Aktivitas yang dipilih oleh guru SDN 10 Pajo yaitu aktivitas yang berhubungan dengan pembelajaran. Hal itu sesuai dengan pendapat Bentham (2004) yang menyatakan bahwa guru sebagai the man behind the guns atau orang utama yang merancang lingkungan belajar bagi siswa, harus selalu mengupayakan untuk menciptakan kondisi lingkungan belajar siswa senyaman dan semenarik mungkin. Oleh karena itu, merujuk pada pendapat tersebut, tepat apabila guru berupaya memberikan aktivitas belajar yang menarik sehingga akan timbul rasa nyaman bagi siswa dan lebih tertarik lagi dengan konteks pembelajaran yang sudah direncanakan oleh guru.

Selain itu, pendapat guru SDN 10 Pajo juga senada dengan pendapat Spergel (2017) yang menyatakan bahwa penggunaan sanksi dengan memberikan aktivitas pengganti yang positif sangat popular digunakan untuk memberikan pengetahuan kepada siswa bahwa ada kegiatan yang lebih positif dibandingkan berperilaku negatif. Merujuk pada pendapat tersebut, tepat sekali bahwa pemberian aktivitas pengganti berupa kegiatan positif akan sangat membantu siswa untuk tertarik lagi pada materi pelajaran atau diskusi.

\section{9) Memanipulasi Lokasi Tempat Duduk Siswa}

Guru di SDN 10 Pajo memanipulasi lokasi tempat duduk siswa untuk mengatasi siswa yang berperilaku agresif dan mencontek. Siswa yang sering berperilaku agresif ditempatkan persis di dekat guru. Guru beralasan bahwa akan lebih mudah dalam mengawasi siswa yang agresif tersebut. Untuk mencontek, guru di SDN 10 Pajo mengkondisikan tempat duduk siswa lebih longgar (renggang) dari biasanya untuk memudahkan pengawasan saat ujian. Cara tersebut sesuai dengan pendapat Morash \& Trojanowicz yang menyatakan bahwa salah satu cara 
penanganan pelanggaran siswa dapat dilakukan dengan teknik Mechanical Prevention (pencegahan mekanik), yang artinya dengan menempatkan pengawas di tempat yang biasanya terjadi pelanggaran. Oleh karena itu, pencegahan dengan memanipulasi tempat duduk sangat efektif karena memang siswa agresif dan suka mencontek memerlukan pengawasan yang lebih khusus.

\section{0) Memberikan Pemahaman Khusus}

Pemahaman khusus digunakan guru untuk mengatasi perilaku mencontek. Guru di SDN 10 Pajo yang memberikan pemahaman tentang esensi dari ujian kepada siswa. Pemahaman itu dilakukan guru SDN 10 Pajo untuk memberikan pengetahuan kepada siswa bahwa nilai kejujuran dari ujian akan sangat membantu guru dalam melakukan perbaikan-perbaikan. Hal itu sesuai dengan Stephens (2001) menyatakan bahwa salah satu tindakan untuk mencegah perilaku mencontek adalah memberikan pemahaman kepada siswa bahwa penguasaan materi (mastery goals) lebih penting dibanding memperoleh nilai yang tinggi tanpa penguasaan (performance goals). Oleh benar bahwa dengan memberikan pemahaman kepada siswa tentang esensi dari tes yang sebenarnya sebagai perbaikan terhadap apa-apa yang belum dikuasai oleh siswa, akan mampu mengurangi perilaku mencontek.

\section{1) Memberikan Kisi-Kisi Belajar}

Pemberian kisi-kisi belajar khusus digunakan guru SDN 10 Pajo untuk mengatasi perilaku mencontek. Guru di SDN 10 Pajo memberikan kisi-kisi untuk digunakan siswa sebagai ramburambu belajar. Tindakan ini tergolong dari tindakan pencegahan. Guru berpendapat bahwa kebanyakan siswa merasa frustasi apabila memang antara tes dan tujuan program pembelajaran tidak cocok atau konsisten. Tindakan itu sesuai dengan pendapat Stephens, dkk. (2001) dan Danielsen, dkk. (2006) yang menyatakan bahwa untuk mengatasi perilaku mencontek dibutuhkan daftar topik tes yang lebih spesifik. Oleh karena itu, dengan memberikan tindakan membuatkan kisi-kisi yang berisi berisi garis- garis besar materi yang akan diujikan, akan dapat mengurangi perilaku mencontek pada siswa.

\section{2) Berkomunikasi dengan Orang Tua Siswa}

Guru SDN 10 Pajo menggunakan cara berkomunikasi dengan orang tua siswa untuk mengatasi permasalahan perilaku mencontek, membuat ancaman fisik dan verbal, membolos sekolah, dan mencuri. Guru di SDN 10 Pajo melakukan komunikasi dengan orang tua siswa. Orang tua yang bersangkutan dipanggil untuk hadir di sekolah kemudian guru menginformasikan bahwa anaknya sering melakukan perilaku mencontek dan membuat ancaman fisik dan verbal. Tindakan tersebut sesuai dengan pendapat Nye yang menyatakan bahwa kehadiran orang tua sangat menentukan perilaku seorang anak. Artinya bahwa kehadiran orang tua di dalam kehidupan sehari-hari anak akan mampu menekan kemungkinan pelanggaran pada anak. Hal itu disebabkan anak merasa mempunyai semacam pengawas sehingga anak akan berhati-hati dalam bersikap. Oleh sebab itu, berkomunikasi dengan orang tua siswa bisa dilakukan oleh seorang guru untuk mengurangi perilaku mencontek pada siswa.

Perihal membolos, Guru SDN 10 Pajo juga melakukan kunjungan atau visitasi ke rumah orang tua yang bersangkutan untuk mencari solusi bersama perihal perilaku membolos yang dilakukan oleh anaknya. Tindakan itu sesuai dengan pendapat Gerrad (2003), Gullat, dkk. (1997) dan Trujillo (2006) yang secara serempak menyatakan bahwa penyertaan orang tua dalam pendidikan memang sangat berkontribusi positif dalam penyelesaian permasalahan perilaku membolos sekolah. Hal itu disebabkan siswa lebih terkontrol, baik oleh guru maupun orang tua. Kontrol tersebut akan menutupi celah siswa untuk membolos sekolah. Oleh sebab itu penyelesaian permasalahan membolos dengan melakukan visitasi atau perlibatan orang tua dalam pendidikan, memang sangat tepat.

Perihal mencuri, Guru SDN 10 Pajo menggunakan cara berkomunikasi dengan orang tua yang bersangkutan untuk menyampaikan permasalahan sampai pada pencarian solusi yang terbaik bagi siswa. Solusi yang diharapkan guru SDN 10 Pajo yaitu orang tua lebih memfasilitasi siswa. Hal itu sesuai dengan apa yang dikatakan Morash \& Trojanowicz dan Spergel bahwa orang tua 
adalah kunci pokok penyelesaian permasalahan, sehingga memang perlu adanya persambungan antara guru dan orang tua siswa yang bersangkutan. Oleh karena itu tepat apabila guru melakukan komunikasi dengan orang tua siswa karena hal tersebut merupakan cara yang utama untuk menyelesaikan masalah mencuri.

\section{3) Memberikan Peraturan}

Penggunaan peraturan ini digunakan guru SDN 10 Pajo untuk mengatasi perilaku mengalihkan pembicaraan dari materi pelajaran atau diskusi dan tidak patuh terhadap arahan guru. Hal itu senada dengan pendapat Morash \& Trojanowicz, dan Crowder, dkk. yang menyatakan bahwa salah satu tindakan preventif yang dapat dilakukan yaitu punitive prevention atau pencegahan untuk mengeliminasi potensi pelanggaran sebelum pelanggaran itu terjadi. Penggunaan peraturan dengan menyertakan konsekuensi logis merupakan salah satu cara pencegahan. Oleh karena itu, pemberian peraturan dengan tujuan pembiasaan memang tepat untuk dilakukan. Pembiasaan tidak hanya menuntut siswa patuh, melainkan menuntut siswa untuk mengetahui konsekuensi dari perilakunya.

Khusus perilaku mengalihkan pembicaraan dari materi pelajaran atau diskusi, guru SDN 10 Pajo menggunakan aturan atau rambu-rambu diskusi. Peraturannya berisi tentang larangan siswa berbicara di luar konteks materi pembelajaran. Hal itu senada dengan pendapat Bentham (2004) yang menyatakan bahwa salah satu bentuk intervensi yang dapat dilakukan oleh guru saat menerangkan atau mengadakan diskusi yaitu dengan selalu mengingatkan siswanya akan peraturan diskusi. Peraturan itu dibuat untuk memberikan "pagar" agar proses diskusi berjalan dengan efektif. Merujuk pada pendapat tersebut, penggunaan rambu-rambu diskusi memang dapat digunakan sebagai cara untuk mengatasi permasalahan perilaku ini.

\section{4) Memberi Pilihan Baik-Buruk}

Guru di SDN 10 Pajo menggunakan cara dengan memberikan pilihan baik dan buruk untuk mengatasi perilaku mengalihkan pembicaraan dari materi pelajaran atau diskusi dan tidak patuh terhadap arahan guru. Siswa diberikan pertanyaan yang tujuannya untuk menyadarkan siswa bahwa perilakunya memang salah sehingga patut untuk memilih perilaku yang lebih baik. Hal itu sesuai dengan pendapat Bentham (2004) yang menyatakan bahwa terkadang seorang guru harus memberikan pilihan disertai konsekuensi sebagai peringatan kepada siswa. Siswa dengan cara berpikirnya digiring untuk menemukan pilihan. Pilihan yang diharapkan yaitu pilihan yang baik. Oleh sebab itu, merujuk pada pendapat tersebut, pemberian pilihan-pilihan baik buruk ini juga dapat dilakukan oleh guru untuk meredam perilaku ini.

\section{5) Pembiasaan}

Guru SDN 10 Pajo memberikan latihan pembiasaan pada siswa untuk mau jujur mengakui kesalahan. Siswa yang telah mau jujur mengakui kesalahannya kemudian diberikan pujian oleh guru SDN 10 Pajo. Tindakan itu sesuai dengan pendapat Bentham (2004) dan Felker yang menyatakan bahwa pujian atau reward memang sesuatu yang paling efektif untuk mengatasi permasalahan perilaku. Pujian yang baik yaitu pujian yang diberikan dengan segera sesaat kemudian setelah perilaku yang positif dilakukan oleh siswa sehingga siswa mengetahui perilaku apa yang mendapatkan pujian dan mau mengulangi perilaku tersebut. Merujuk pada pendapat tersebut, memang cara yang digunakan oleh guru dengan menggunakan pujian memang suatu tindakan yang cocok untuk mengatasi perilaku ngeyel (tetap berbicara dan tidak mau mengakui kesalahan).

\section{6) Memberi Pengalaman Gagal}

Guru SDN 10 Pajo memberikan pengalaman yang membuat siswa mau mengakui kesalahan. Pengalaman yang diberikan sudah di setting bahwa siswa pasti akan melakukan kesalahan. Hal itu sesuai dengan pendapat Felker yang menyatakan bahwa pengalaman kegagalan memang perlu dan harus dihadapi oleh setiap siswa. Harapannya siswa mau belajar untuk melakukan evaluasi yang lebih realistis terhadap dirinya sendiri. Merujuk pada pendapat tersebut, tepat apabila siswa diberikan setting suatu kegiatan untuk memberikan pengalaman kegagalan agar siswa melakukan evaluasi yang realistis terhadap dirinya karena muncul perasaan bersalah dan 
akhirnya mereka merasa wajib untuk memperbaiki diri dari kesalahannya.

\section{7) Memberi Motivasi}

Guru SDN 10 Pajo memberikan motivasi untuk membesarkan hati siswa yang kerap membolos dengan ditambah upaya dari guru untuk selalu memperbaiki proses pembelajaran. Hal itu senada dengan pendapat Gerrad (2003) dan Trujillo (2006) yang menyatakan bahwa memang benar bahwa salah satu upaya untuk mengatasi permasalahan membolos yaitu dengan memberikan motivasi kepada siswa yang bersangkutan. Salah satu upaya motivasi itu menyelenggaran praktek pendidikan yang mampu memenuhi segala kebutuhan belajar siswa, meliputi kenyamanan lingkungan belajar secara fisik maupun sosial-psikologis. Oleh sebab itu memberikan motivasi kepada siswa dengan memperbaiki pembelajaran memang tepat dilakukan oleh guru guna mengatasi permasalahan perilaku membolos sekolah.

\section{8) Berkomukasi Secara Pribadi dengan Siswa}

\section{(Privat Chat)}

Guru menggunakan cara private chat dengan siswa untuk mengatasi perilaku mencuri. Guru SDN 10 Pajo melakukan wawancara secara khusus dengan siswa untuk mencari penyebab perilaku mencuri ini dilakukan. Hal itu sesuai dengan pendapat Bentham (2004) menyatakan bahwa salah satu solusi yang dapat diterapkan dalam mengatasi permasalahan perilaku yaitu dengan cara private chat with student (wawancara secara khusus dengan siswa). Wawancara khusus bertujuan untuk mencari tahu permasalahan yang dihadapi siswa sehingga dapat ditemukan juga solusi permasalahan dengan bantuan guru. Oleh karena permasalahan perilaku mencuri ini kompleks, bahkan sebenarnya kapasitas masalah ini sangat berat bagi seorang siswa, maka penggunaan wawancara khusus ini sangat cocok diterapkan untuk mengasi permasalahan ini.

\section{Dikembalikan kepada Orang Tua}

Guru SDN 10 Pajo menggunakan cara ini untuk mengatasi perilaku mencuri. Siswa yang kedapatan telah mencuri berulang kali dikembalikan oleh guru SDN 10 Pajo kepada orang tua. Hal itu sesuai dengan pendapat Dweretzky (1990) yang menjelaskan bahwa ada sebuah teknik penyelesaian masalah pelanggaran dengan love withdrawal, yaitu cara seorang guru mengungkapkan ketidaksetujuan dengan mengabaikan, mengucilkan, serta mengekspresikan ketidaksukaan terhadap siswa. Berkaitan dengan mengembalikan siswa yang mencuri kepada orang tua, berarti guru melakukan teknik love withdrawal, yaitu dengan mengembalikan siswa kepada orang tuanya. Mengembalikan ini dapat diartikan dengan mengucilkan karena guru dengan sengaja memisahkan siswa yang mencuri dengan seluruh warga sekolah. Oleh karena itu memberikan sanksi dikembalikan kepada orang tua merupakan cara yang tepat untuk mengatasi permasalahan ini.

\section{SIMPULAN DAN SARAN}

\section{A. Simpulan}

Hasil penelitian terhadap respon guru SDN 10 Pajo tentang pelanggaran siswa yaitu: 1) Pelanggaran siswa adalah perilaku menyimpang yakni dengan melanggar peraturan sekolah, sehingga mengganggu suasana belajar dan merugikan individu lain; 2) Bentuk pelanggaran siswa dikategorikan menjadi 2, yaitu pelanggaran siswa berupa perilaku mengganggu dan pelanggaran serius siswa. Perilaku mengganggu diresponkan beragam meliputi: tidak memperhatikan kerapian, tidak memperhatikan penjelasan guru, agresif; mencontek, membuat ancaman fisik dan verbal kepada guru atau siswa, mengalihkan pembicaraan dari materi pelajaran atau diskusi, tidak patuh terhadap arahan guru, Ngeyel (tetap berbicara dan tidak mengakui kesalahan), sedangkan pelanggaran serius siswa meliputi: perilaku membolos dan mencuri; 3) Beragam respon guru menyebutkan bahwa ada 6 penyebab pelanggaran siswa yaitu: kondisi fisik, kurangnya perhatian orang tua (pendidikan moral dan dukungan ekonomi), metode pembelajaran guru yang kurang bervariasi (monoton), bahasa yang digunakan guru sulit untuk dipahami siswa, faktor lingkungan yang negatif, dan materi pelajaran terlalu banyak; 4) Beragam respon guru mengenai cara mengatasi pelanggaran siswa, yaitu: pemberian model bagi siswa, teguran verbal, sanksi fisik, perhatian khusus, memanipulasi pemberian tugas, memberikan aktivitas pengganti, memanipulasi 
lokasi tempat duduk, memberikan pemahaman khusus, memberikan kisi-kisi belajar, berkomunikasi dengan orang tua, memberikan peraturan, memberikan pilihan baik-buruk, pembiasan, memberikan pengalaman gagal, memberikan motivasi, berkomukasi secara pribadi dengan siswa, dan dikembalikan kepada orang tua.

\section{B. Saran}

Penelitian ini hanya terbatas di SDN 10 Pajo saja. Oleh karena itu, bagi peneliti selanjutnya agar dapat mengembangkan hasil penelitian ini dengan sumber data yang berbeda guna memperkaya kajian ilmu di bidang pendidikan dasar dan psikologi, khususnya kajian mengenai pelanggaran siswa yang belum terungkap dalam penelitian ini, Guru SDN 10 Pajo diharapkan membaca hasil penelitian ini karena akan sangat berguna untuk merekonstruksi pemahaman pelanggaran siswa, khususnya berkaitan dengan perilaku tidak memperhatikan kerapian.

\section{DAFTAR RUJUKAN}

Enung Nurhasanah. (2021). Pengembangan Multimedia Pembelajaran Sejarah Perkembangan Islam Berbasis Macromedia Flash untuk Meningkatkan Hasil Belajar Mahasiswa. Ainara Journal (Jurnal Penelitian Dan PKM Bidang Ilmu Pendidikan),2(3), 148-153. Retrieved from http://journal.ainarapress.org/index.php/ainj/article/view/69

Gerrad, D., Burhans, A., \& Fair, J. 2003. Effective Truancy Prevention And Intervention (A Review of Relevan Research For Hennepin County School Success Project). Minnesota: Wilder Research Center.

Hanurawan, F. 2012. Psikologi Sosial Terapan Dan Masalah -Masalah Perilaku Sosial. Malang: Fakultas Ilmu Pendidikan Unversitas Negeri Malang.

Herlan, P. \& Fatchurahman, M. 2012. Kematangan Emosi, Konsep Diri, dan Pelanggaran Remaja. Jurnal Personal, Universitas 17 Agustus 1945, 1(01): 6-14

Ija Srirahmawati. (2021). Peran Guru Sebagai Fasilitator dalam Mengasah Penalaran Matematika Siswa SDN 29 Dompu Tahun Pembelajaran 2020/2021. Ainara Journal (Jurnal Penelitian Dan PKM Bidang Ilmu Pendidikan),2(2), 114-123. Retrieved from http://journal.ainarapress.org/index.php/ainj/article/view/40

Kartini Kartono, Psikologi Anak (Psikologi Perkembangan) (Bandung: CV.Mandar Maju, 2007), hal. 227.

Mangunwijaya, Y. B. 2006. Memuliakan Allah Mengangkat Manusia. Yogyakarta: Kanisius.

Muhammad Amin. (2021). Upaya Meningkatkan Kemampuan Bertanya Siswa dengan Pola Berjenjang dalam Pembelajaran PPKN di Kelas X IPA 3 SMA Negeri 2 Dompu Tahun Pembelajaran 2019/2020. Ainara Journal Uurnal Penelitian Dan PKM Bidang Ilmu Pendidikan), 2(1), 1-7. https://doi.org/10.1234567/ainarajournal.v2i1.18

Putri Emilia. (2021). Upaya Meminimalisir Kenakalan Siswa Melalui Identifikasi Sebab pada Kelas XI SMA Negeri Woja Kabupaten Dompu Tahun 2018/2019. Ainara Journal (Jurnal Penelitian Dan PKM Bidang Ilmu Pendidikan), 2(1), 8-19. https://doi.org/10.1234567/ainarajournal.v2i1.19

Sarwono, S.W. (2001). Psikologi Remaja. Jakarta: Rajawali Pers.

Satiadarma, M.P. 2001. Respon Orang Tua Membentuk Perilaku Anak: Dampak Pygmalion di Dalam Keluarga. Jakarta: Pustaka Populer Obor.

Tejada, A. N. 2007. Facts For Families: Children Who Steals. USA: American Academy of Child \& Adolescent Psychiatry. 
Trujillo, L.A. 2006. School Truancy: A Case Study at Successful Reduction Model In Public School. US Davis Journal of Juvenille Law \& Policy, 10(1).

Willis, S.S. 2005. Remaja dan Masalahnya (Mengupas Berbagai Bentuk Pelanggaran Remaja Seperti Narkoba, Free Sex dan Pemecahannya. Bandung: Alfabeta. 